\title{
Zwemer Hall:
}

\section{A Landmark at Northwestern College}

Nelson Nieuwenhuis

ZWEMER HALL WAS THE FIRST edifice built on the campus of Northwestern College in Orange City, Iowa. Over the years this unique building, with its graceful lines and stately tower, has provided hundreds of illustrations for school catalogs, annuals, brochures, and other publications. Throughout its history Zwemer Hall has been the center of school activities. Today it houses the administrative offices of Northwestern, and serves as the regional headquarters for the Dutch Reformed Church in America. The building has recently been added to the National Register of Historic Sites.

It was a warm summer day in July, 1882, when the Act of Incorporation was drafted for Northwestern Classical Academy. This took place just twelve years after the founding of the Dutch settlement in Sioux County, Iowa. Early in August a paper was circulated soliciting funds for the school, and a man named Henry Hospers donated a block of land for a campus in the "South Addition" of Orange City.

In the fall of 1883 , the principal of the public school in Orange City, assisted by some ministers of the area, began to prepare a few young men for Academy work. Formal opening of the school took place on September 23, 1883, at 9 A.M. with twelve students in attendance. By the end of the second week, the number of students had increased to twenty-five.

Funds were collected in the community for the purpose of erecting a temporary school building on the newly acquired campus. This building became known as the "Pioneer School." While 
this building was under construction, the preparatory instruction was carried on in the consistorial chamber of the First Church, or in the public school. The site for the campus was selected by the members of the Board of Trustees, who one day in August, 1882, made a personal inspection of the grounds. One of the men noted that the site was near the "historic old wind-mill"."

This was the location for Northwestern's first campus. Members of the board looked forward to the time when a "permanent" building could be erected on the property. Hopes were suddenly set aside by the totally unexpected disaster which struck the community in 1873. Without warning, on a Sunday afternoon in July of that year, and while the people were at church, hordes of locusts swooped down out of the skies and within a few hours completely destroyed the ripening grain. It was not until 1879 that the community saw the last of these destructive visitations. In commenting on this period, the Reverend Seine Bolks, pioneer preacher of the colony, remarked, "the grasshoppers flew away with our hopes." 2

The decade of the 1880s brought abundant harvests, and hopes were renewed for the establishment of a school of higher learning for the Sioux County colony. Along with the hopes for a school, came also the desire for the more "permanent" building to house the institution. By 1886 , the student body had increased in numbers to such an extent that the Board found it necessary to seek larger quarters. At this time, the Town Hall became available. It was a two-story building, 100 feet in length. The upper storey had been used as a skating rink. It was located downtown about where the present City Hall now stands. The students came to call the building, "Noah's Ark," or "the rink."

The Principal, James F. Zwemer, remarked, if the cradle of the Academy was in the 'Pioneer School', it was in the 'Rink' that we learned to walk. It was nicknamed by some an Ark; and indeed, it became

'D. Gleysteen, Illustrated Atlas of Sioux County, Iowa, 1908, 6. The windmill was erected in 1875 , by Hyman Den Hartog, and was located west of De Valois Field and near the College Auditorium. Here wheat was ground into flour for the early settlers. The giant "sails" of the mill could be seen turning in the wind from miles distant. It was a familiar landmark for many years. The machinery for the mill came from the Netherlands. With the coming of the railroad, and gasoline power in the later 1880 s, the old mill was torn down, much to the regret of the pioneers.

${ }^{2}$ De Volksvriend (Orange City, Iowa), January 17, 1884. 
(through the wonderful gift of a friend in the East) an Ark of Salvation. There we were kept; there we grew and grew from strength to strength; there the students came as doves to their windows, from there systematic efforts to self-reliance began; and from there the blessed Providence led us to a permanent place of living, where we wish to remain with the youth entrusted to us. ${ }^{3}$

In 1886 classes were held in Academy Hall downtown in rooms on the second floor, with dormitory facilities on the first floor. The Pioneer School building was made into a residence for the principal. The first years following the moving to Academy Hall, little action was taken towards the erection of a more permanent building on the campus. Lack of funds may have been the reason: the minutes of the board, June 17,1891 reveal that there was a debt of $\$ 4,000$ which included $\$ 1,075$ due the professors.

A year passed by with no further action recorded in the minutes regarding a new building, until September 20,1892. At that time a plan was suggested by the principal, and a committee consisting of Reverend James F. Zwemer and Henry Hospers was appointed to canvass the town to obtain funds for erection of a building.

In May of that year Professor Zwemer reported that "more than $\$ 10,000$ had been subscribed." In June the Board decided "to proceed toward the erection of a $\$ 15,000$ building, at least during this year." Then in September a decision was made to halt progress on the building project "on account of the stringency of the times." Henry Hospers, the treasurer of the board, asked to be excused. The action taken not to proceed further with the plans must have been a bitter disappointment to those men who had worked so hard to get the project under way. As the principal had earlier pointed out, there was a "pressing need for a new building."

Hospers, as president of the Orange City Bank, was well aware of the financial situation in the community, and also in the nation at large. The United States was in the grip of the Panic of '93. Since March there had been a number of bank failures throughout the country, and business enterprises had closed down. The crisis was felt most acutely in the farming communities, and government was not organized to give aid to the rural areas.

${ }^{3}$ De Volksvriend, December 6, 1894. 
In February, 1894, a special meeting was called for February 7 at the residence of the Reverend Seine Bolks, president of the board of trustees. The building committee was directed by the board to advertise for public bids for the construction of the New Academy Building.

After seven weeks, the Northern Building Company of Sioux City, Iowa won the bid at $\$ 12,950$. This historic meeting was held at the residence of the aged pioneer preacher, the Reverend Bolks, and the heart of this old gentleman must have rejoiced to see steps being taken toward the realization of his hopes and prayers. Mr. Bolks was then 80 years of age and in failing health.

The contract called for the erection of the new building according to the plans and specifications of architect George Pass. ${ }^{4}$ The stone used was described as being very strong, of low porosity, high tensile strength and possessing a great deal of color variation.

The ceremonies in connection with the laying of the cornerstone coincided with commencement week. This was the ninth annual commencement, which took place during the week of June $17-23,1894$. The first event was the Alumni "sociable" held on Wednesday evening at the Court House building in the park. The Sioux County Herald, a local weekly, reported that there were fifty Alumni present at this gala affair out of a total of seventy-six Alumni of the institution; it was considered a very successful event. A reporter for the Herald noted:

Thursday morning the members of the Board of Trustees held a meeting. The affairs of the institution were found to be in a most gratifying condition. The work done by the teachers during the past year was so satisfactory they all were engaged again. J. F. Zwemer was chosen Principal; E. C. Oggel was offered the chair of mathematics; A. Te Paske, English and Greek; Miss Fannie Steffens, German and Latin. ${ }^{5}$

4The Mankato Daily Free Press (Mankato, Minnesota), June 9, 1931. George Pass came from Mankato, Minnesota. He was born in Pella, Iowa on July 26, 1848 , the son of pioneer Dutch parents. Pass worked at the building trades in Chicago, New Orleans, and Minneapolis before moving to Mankato, where he lived for more than fifty years. He was the founder of the architectural firm known as Pass, Rockey, and Church. During his career he built more than seventy-five churches in the Midwest. In Mankato he built a number of schools, the Saulpaugh Hotel, and the Y.M.C.A. building. He was active in business and civic affairs in Mankato until his death in 1931.

${ }^{5}$ Sioux County Herald, (Orange City, Iowa), June 27, 1894. 


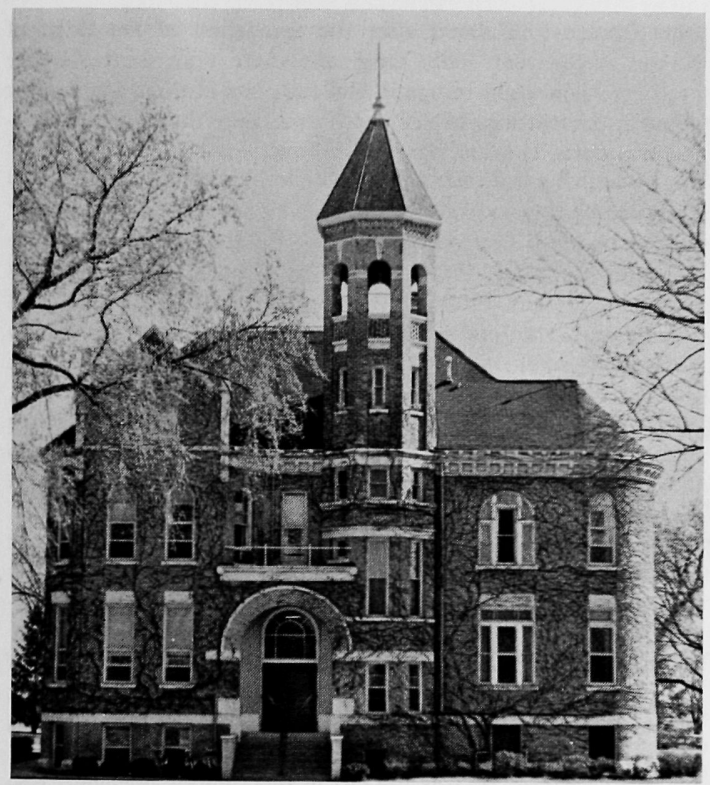

Courtesy of author

Zwemer Hall on the campus of Northwestern College, Orange City, Iowa.

On Thursday June 21,1894 , at 1:30 o'clock, students, faculty, Board members, and friends gathered at the site of the New Academy Building for the ceremonies-the laying of the cornerstone.

As part of the ceremonies, Principal J. F. Zwemer deposited within the corner stone a copy of the Sioux County Herald, De Vrye-Hollander, De Volksvriend, the Classic, and other articles. An original poem composed for the occasion by the Reverend Adriaan Zwemer was read by the author. He was the father of the principal, and was visiting his son during the eventful week.

The Zwemer family was among those Huguenots who fled 
from France to Holland after the revocation of the Edict of Nantes in the year 1685 . Originally there were three Zwemer brothers who sought refuge in Holland, one of them making his home in the Province of Zeeland. It was here that Adriaan Zwemer was born. The family name in France was spelled "Sur-Mer" but while living in Zeeland Province the name came to be spelled Zwemer, making it easier for the Dutch to pronounce the name. ${ }^{6}$

The board of Trustees on April 14, 1924, decided to name the Academy Building "Zwemer Hall" in honor of the principal James F. Zwemer. Professor Zwemer died in 1921 at the age of seventy one. The New Academy Building finally had a name; a name made up of Dutch and French syllables, "Zwe" to represent the Dutch element, and "Mer" the French Hugenot influences. Thus the name "Zwemer" can be said to be symbolic of the Dutch and French Huguenot families who together lived and worked to make the Sioux County settlement and Northwestern Classical Academy a success.

There was one event during that memorable commencement week which had not been scheduled, but which nevertheless was significant. On Tuesday, June 19, funeral services for the Reverend Seine Bolks were held in the local First Reformed Church. Board members, faculty, and many friends joined the members of the congregation at First Church to honor the memory of this pioneer preacher of the Gospel. "Father Bolks" had labored long and faithfully for the people of the Sioux County settlement, and for Northwestern. He was the last of five pioneer preachers who led congregations from the Netherlands to America in 1847.

In late November the final finishing touches were made on the building, and the long-awaited dedication services held. Two special gatherings were planned for November 23 - the first at 1:30 P.M. in the First Reformed Church, and the second, at 3 P.M. in the new Chapel of Zwemer.

A reporter for the Sioux County Herald described the scene: "At half-past one o'clock on Tuesday the faculty and students walked in procession from the old Academy Hall to the church where the first of the dedicatory exercises took place. The large audience that had gathered assured those present of the deep(1932).

'Samuel M. Zwemer, Genealogy and History of the Zwemer-Boon Family, 


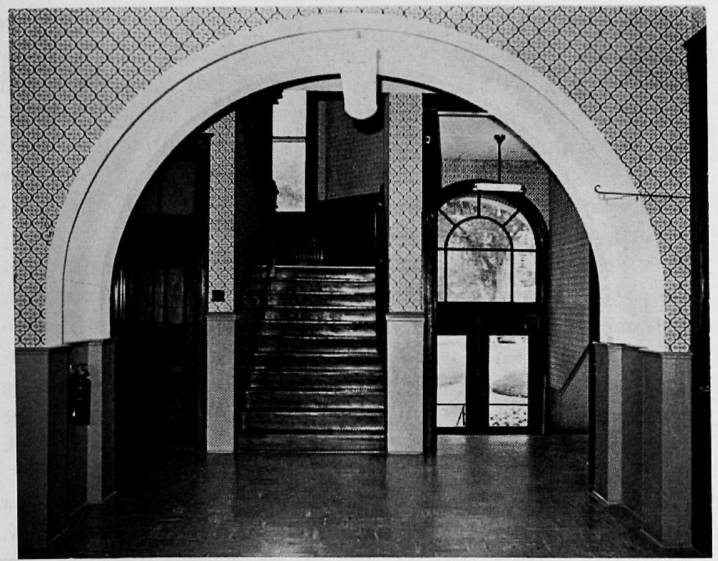

Interior view of Zwemer Hall

Courtesy of author

seated and general interest the community has in the Academy and in education generally."

The service was in the Dutch language, and opened with the singing of the Doxology, and prayer by the Reverend James De Pree of Sioux Center, Iowa. Scripture was read by the Reverend Henry Straks of Maurice, Iowa. Some Dutch Psalms were sung and Principal Zwemer spoke words of welcome. "The new building," he said, "is a cause of gratitude and hope. It is a House of God as well as any church. Help us realize its purpose by sending to it your sons and daughters. It is my prayer that some day, in the Will and Providence of God, that the new building may become the home of a college."'

Following the service the student body, some sixty in number, formed in procession outside with the four faculty members and friends to walk the mile to the new building. They made their way southward over the dirt road past the business places and the old Academy Hall, or "Ark." As they moved down Central Avenue 
the new building with its stately tower could be clearly seen directly ahead of them, the bright sun reflecting from the new wood shingles of the roof. Soon they reached the campus and mounted the solid stone steps leading into the building. Once inside, the group ascended the wide stairway leading to the second floor and took places in the spacious Chapel Hall. The Orange City Town Band was playing a medley of numbers for the entertainment of those who had come early.

A dramatic moment in the program came when the Hon. Henry Hospers came forward, made a few appropriate remarks, and then, in the name of the Board of Trustees, presented Principal Zwemer with a gold-studded cane as a token of appreciation. As reported in the local Herald, "In words full of feeling Professor Zwemer responded with thanks." After a hymn, the benediction was pronounced by the Rev. John Huizinga, of Rock Valley, Iowa.

After dismissal the people walked about inspecting the new facilities inside and out, and were delighted with what they saw. There was much to admire, and the people might well exclaim with the Psalm writer: "Strength and beauty are in his sanctuary."

Althou'gh eight decades have passed, Zwemer Hall today is still beautiful to behold. There is not only strength and beauty, but also balance and proportion in its arrangement of parts. Viewing it from the north one's attention is drawn to the great Roman arch placed above the steps to the main entrance. An exterior balcony is found just above the arch. Each side of the structure displays a unique character all its own, with a variety of intricate window arrangement and design. Three sides have strong flat buttresses which are imperceptibly joined with the large gables on the roof. Where wall meets roof classic cornices add to the delicateness of the ornamentation.

The northwest portion of the building offers a surprise to the viewer. The walls unite to form a large circular extension which gives the appearance of a medieval tower with its circular wall and roof.

Zwemer Hall's graceful tower is hexagonal in design, topped by a hexagonal roof, and rises from the ground level to a height of some 80 feet. The tower is joined subtly with the front entrance archway and part of the north wall, lending beauty to the front 


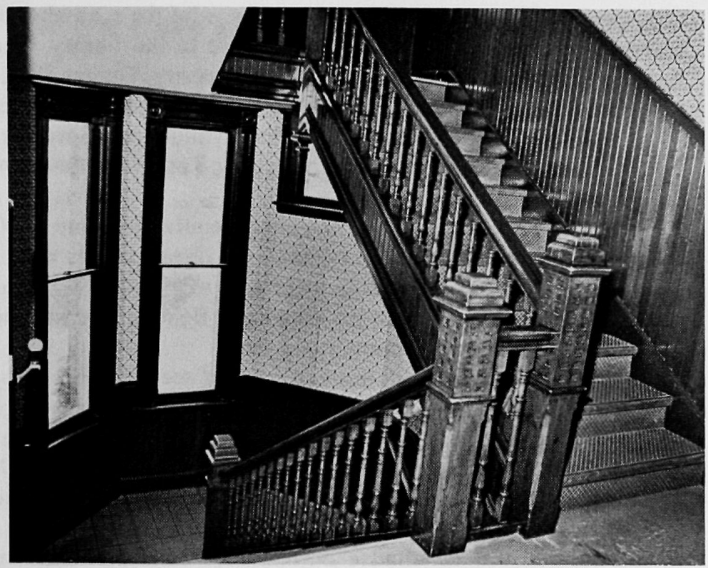

Interior staircase in Zwemer Hall

Courtesy of author

and also serving as a buttress. It contains five tiers of windows with varied window patterns for each tier, the upper rank of six windows are open and topped with Roman arches.

The architect, George Pass, was an apt pupil of one of America's greatest architects-Henry Hobson Richardson (1838-1886). Zwemer Hall illustrates all of the characteristics of this famous builder, for it reveals, "a romantic and picturesque mass effective from any angle, a texture, sometimes of roughly hewn stone, often of brick, high roofs, clustered windows, deeply arched doorways, an achievement of beauty through strength."

Upon entering the main doorway there is a short flight of steps and we find ourselves inside a large hallway. Directly above a great Roman arch extends majestically across the width of the hall. A wide stairway leads to the second floor. In the northwest portion of the hall are two doors which provide entrance into the Rapelye Library and Reading Rooms. It was so named to honor

'Thomas Eddy Tallmadge, The Story of Architecture in America, (New York: W. W. Norton \& Co., 1936), 166-194. 
Mrs. Cornelius Rapelye, of New York City, who for a number of years donated money, books, and furniture to the library. The Rapelye family were of French Huguenot ancestry. George Rapelye came to America along with many other Huguenots settling on Manhattan Island at the time when Peter Minuit was Governor. The Dutch spelling of the name Rapelye, or Rapelije, came from the French-Rapelier.

In 1895 it was estimated that the library contained some 3,000 volumes. The interior partition between the library rooms was of unique design. Beneath a large arch was a window of etched glass, with arched doors, one on each side. Beneath the window was a shelf finished with maple wood trim.

In other parts of the building were classrooms, a science laboratory, a Ladies Study Room, and on the second floor a large Chapel auditorium with two side annexes, and a Latin Room located above the library. Maple wood floors and trim, with wainscoting beautifully finished, added to the appearance of the interior.

Northwestern at last had a permanent building on its own campus. All of this must have given great satisfaction, especially to Professor James F. Zwemer and Henry Hospers. Both had given their time, energy and funds for Northwestern. Zwemer had called upon almost every family in the Dutch settlement. He expressed pleasure in the fact enough money had been collected to pay for the entire cost of the new building, which came to $\$ 16,000$. He said, "Almost every one approached for gifts had contributed something. The building is gracefully and appropriately constructed to its purposes. Above all, we thank God, for it has been ever He that has crowned our efforts with success."

Henry Hospers, the founder of the Sioux County settlement, from the very first had striven for adequate schools for the people. He was active in setting up public schools throughout Sioux County, serving for a time as superintendent of schools, and as a member of the Sioux County Board of Supervisors. He subsequently spent seventeen years as treasurer of the Board of Trustees of Northwestern Classical Academy, and gave generously of his land and money for the school. 
Copyright of Annals of Iowa is the property of State of Iowa, by \& through the State Historical Society of Iowa and its content may not be copied or emailed to multiple sites or posted to a listserv without the copyright holder's express written permission. However, users may print, download, or email articles for individual use. 